\section{KiSS1 inhibits growth and invasion of osteosarcoma cells through inhibition of the MAPK pathway}

\author{
Y. Zhang, Y.J. Tang, Z.H. Li, F. Pan, \\ K. Huang, G.H. Xu
}

Department of Orthopedics, Zhabei

District Central Hospital, Shanghai, China

\section{Abstract}

As a metastasis suppressor, KiSS1 has been implicated in numerous human cancers. However, recent studies have demonstrated that KiSS1 promotes tumor growth and metastasis in breast cancer, and it is unclear about the expression and function of KiSS1 in human osteosarcoma (OS). The aim of the present study was to investigate the role and molecular mechanisms of KiSS1 in human OS. The expression of KiSS1 was assessed by immunohistochemical assay using a tissue microarray procedure in forty cases of OS tissues. A gain-of-function approach was used to observe the effects of lentiviral vector-mediated overexpression of KiSS1 (Lv-KiSS1) on the biological behaviors including proliferative activities and invasive potential of OS MG-63 cells, indicated by MTT and Transwell assays, respectively. The results showed that the expression of KiSS1 protein in OS tissues was significantly lowered compared to that in adjacent non-cancerous tissues ( $42.5 \%$ vs $70.0 \%$, $\mathrm{P}=0.023)$, and had negative correlation with distant metastases of the tumor $(\mathrm{P}=0.019)$. Overexpression of KiSS1 inhibited proliferation and invasion of OS cells with the decreased expression of p38 MAPK and matrix metalloproteinase-9 (MMP-9). Taken together, our findings indicate that the decreased expression of KiSS1 is correlated with distant metastasis of OS, and KiSS1 may function as a tumor suppressor in OS cells through inhibition of the MAPK pathway, suggesting that KiSS1 may serve as a potential therapeutic target for the treatment of cancer.

\section{Introduction}

Osteosarcoma (OS) is the most common type of primary malignant bone tumor in children and adolescents and generally follows an aggressive clinical course. ${ }^{1}$ OS is a highly aggressive neoplasm that is resistant to current therapeutic approaches, including radiation, chemotherapy, and surgical treatment.
Although 5-year survival rates of OS up to $50-70 \%$ can be achieved by using current treatment protocols, a substantial group of patients with metastatic, recurrent, and refractory disease remains without effective treatment options. ${ }^{2,3}$ Tumor is also a genetic disease, and develops in a multi-step process; single or multiple mutations in genes related to growth control and metastasis form the molecular genetic basis of malignant transformation and tumor progression. Therefore, identification of molecular targets that can be exploited in the clinic to treat metastatic disease is desperately needed.

The KiSS1 metastasis suppressor gene has emerged as a promising molecular target for the management of metastatic disease. KiSS1 has been intensively studied in physiology with diverse functions including the expression in the human and rat carotid body and superior cervical ganglion, ${ }^{4}$ but its role in cancer is still unclear. The whole genome microarray analysis identifies KiSS1 to be important in the progression and prognosis of metastatic cancers. ${ }^{5}$ Numerous clinical reports demonstrate that a loss or reduction of KiSS1 expression in different human cancers inversely correlates with tumor progression, metastasis, and survival..$^{6-8}$ The diagnostic and prognostic utility of KiSS1 methylation also suggests its assessment for the clinical management of cancer patients. ${ }^{9,10}$ Moreover, KiSS1 mediates platinum sensitivity and metastasis suppression in head and neck squamous cell carcino$\mathrm{ma}^{11}$ and pancreatic adenocarcinoma, ${ }^{12}$ suggesting potential targets for therapy in cancers. However, some studies have shown that KiSS1 plays a role in promoting tumor development. KiSS1 expression is found to be increased and correlates with poor prognosis of hepatocellular carcinoma ${ }^{13}$ and estrogen receptor-positive breast tumors, ${ }^{14,15}$ suggesting an independent prognostic marker for tumor aggressiveness. To elucidate the function of KiSS1 in cancer, in the present study, the expression of KiSS1 in OS tissues was assessed by an immunohistochemical (IHC) assay using a tissue microarray procedure, and a gain-of-function approach was employed to investigate the effects of KiSS1 overexpression on the biological behaviors including proliferative activities and invasive potential of OS MG-63 cells, indicated by MTT and Transwell assays, respectively. We hypothesize that KiSS1 might serve as a potential therapeutic target for the treatment of cancer.

\section{Materials and Methods}

\section{Materials}

The OS MG-63 cell line used for experi-
Correspondence: Yong Zhang, Department of Orthopedics, Zhabei District Central Hospital, No.619 Zhonghuaxin road, Zhabei District, Shanghai 200070, China.

E-mail: zhangyongzb@163.com

Key words: KiSS1, osteosarcoma, growth, invasion.

Contributions: YZ, experimental arrangement and design, experiment performing and manuscript writing: YJT, experiment performing; ZHL, experimental arrangement; FP, KH, data collection; GHX, data analysis.

Conflicts of interest: the authors declare no conflicts of interest.

Received for publication: 5 July 2013.

Accepted for publication: 17 September 2013.

This work is licensed under a Creative Commons Attribution NonCommercial 3.0 License (CC BYNC 3.0).

CC Copyright Y. Zhang et al., 2013

Licensee PAGEPress, Italy

European Journal of Histochemistry 2013; 57:e30 doi:10.4081/ejh.2013.e30

ments was obtained from the Institute of Biochemistry and Cell Biology (Shanghai, China). Lentivirus-mediated KiSS1 vector, negative control vector, and virion-packaging elements were purchased from Genechem (Shanghai, China); KiSS1 and p38 MAPK primers were synthesized by ABI (Framingham, MA, USA). The tissue microarray of human OS was purchased from the branch of Biomax (Xi'an, China). All antibodies were obtained from Santa Cruz Biotechnology (Dallas, TX, USA).

\section{Drugs and reagents}

Dulbecco's Modified Eagle medium (DMEM) and fetal bovine serum (FBS) were purchased from Thermo Fisher Scientific Inc. (Waltham, MA, USA); TRIzol Reagent and Lipofectamine 2000 were obtained from Invitrogen (Carlsbad, CA, USA); M-MLV Reverse Transcriptase was purchased from Promega (Madison, WI, USA); SYBR Green Master Mix was obtained from Takara (Otsu, Japan); and the ECL Plus Kit was obtained from GE Healthcare (Piscataway, NJ, USA).

\section{Clinical samples and data}

A tissue microarray was prepared for the IHC test using a total of 40 consecutive cases of human OS tissues and corresponding adjacent non-cancerous tissue (ANCT), which were collected from the Orthopedics Department of Shanghai Zhabei District Central Hospital from January 2007 to 
December 2011. The study was approved by the Medical Ethics Committee of Shanghai Zhabei District Central Hospital, and written informed consent was obtained from the patients or their parents before sample collection. All the cases were reviewed by two pathologists.

\section{Tissue microarrays}

For each case, we selected the tumor foci for construction of the tissue microarrays during routine diagnosis by marking them on the hematoxylin-eosin-stained slide using a waterproof pencil. The Advanced Tissue Arrayer (ATA-100; Chemicon International, Tamecula, CA, USA) was used to create holes in a recipient paraffin block and to acquire cylindrical core tissue biopsies with a diameter of $1 \mathrm{~mm}$ from specific areas of the donor block. The tissue core biopsies were transferred to the recipient paraffin block at defined array positions. The resulting tissue microarrays contained tissue samples from 40 formalin-fixed, paraffinembedded cancer specimens with known diagnosis and correlated benign tumor tissues from patients.

The block was incubated in an oven at $45^{\circ} \mathrm{C}$ for 20 min to allow complete embedding of the grafted tissue cylinders in the paraffin of the recipient block and then stored at $4^{\circ} \mathrm{C}$ until microtome sectioning.

\section{Immunohistochemical staining}

Anti-KiSS1 antibody was used for IHC detection of the expression of KiSS1 protein in tissue microarrays. Tissue microarray sections were processed for IHC analysis of KiSS1 protein as follows. Immunohistochemical examinations were carried out on $3 \mathrm{~mm}$ thick sections. For anti-KISS1 immunohistochemistry, unmasking was performed with $10 \mathrm{mM}$ sodium citrate buffer, $\mathrm{pH} 6.0$, at $90^{\circ} \mathrm{C}$ for $30 \mathrm{~min}$. For anti-KISS1 immunohistochemistry, antigen unmasking was not necessary. Sections were incubated in $0.03 \%$ hydrogen peroxide for 10 $\mathrm{min}$ at room temperature, to remove endogenous peroxidase activity, and then in blocking serum $(0.04 \%$ bovine serum albumin, A2153, Sigma-Aldrich, Shanghai, China and $0.5 \%$ normal goat serum X0907, Dako Corporation, Carpinteria, CA, USA, in PBS) for $30 \mathrm{~min}$ at room temperature. Anti-KiSS1 antibody was used at a dilution of 1:200. The antibody was incubated overnight at $4^{\circ} \mathrm{C}$. Sections were then washed three times for 5 min in PBS. Non-specific staining was blocked with $0.5 \%$ casein and $5 \%$ normal serum for $30 \mathrm{~min}$ at room temperature. Finally, staining was developed using diaminobenzidine substrate, and sections were counterstained with hematoxylin. Normal serum or PBS was used to replace anti-KiSS1 antibody in negative controls.

\section{Quantification of KiSS1 protein expression}

KiSS1 expression was semiquantitatively estimated as the total KiSS1 immunostaining score, which was calculated as the product of a proportion score and an intensity score. The proportion score reflected the fraction of positively stained cells (score $0,<5 \%$; score $1,5 \%$ 10\%; score 2, 10-49\%; score 3, 50\%-75\%; score $4,>75 \%)$. The intensity score represented the staining intensity (score 0, no staining signal; score 1 , weak positive signal; score 2 , moderate positive signal; score 3 , strong positive signal). Finally, a total expression score was given, ranging from 0 to 12 . The score 0 was regarded as negative, score 1-3 was regarded as + , score 4-6 was regarded as ++, score 7-9 was regarded as +++ , and score $10-12$ was regarded as ++++. Two observers estimated the total immunostaining score, independently and blindly. The total score reported was the average of two observers.

\section{Cell culture and transfection}

MG-63 cells were cultured in DMEM medium supplemented with $10 \%$ heat-inactivated FBS, $100 \mathrm{U} / \mathrm{mL}$ of penicillin, and $100 \mu \mathrm{g} / \mathrm{mL}$ of streptomycin. Cells in this medium were placed in a humidified atmosphere containing $5 \% \mathrm{CO}_{2}$ at $37^{\circ} \mathrm{C}$. Cells were subcultured at a 1:5 dilution in medium containing $300 \mu \mathrm{g} / \mathrm{mL}$ G418 (an aminoglycoside antibody, commonly used as stable transfection reagent in molecular genetic testing). On the day of transduction, MG-63 cells were replated at $5 \times 10^{4}$ cells/well in 24-well plates containing serumfree growth medium with polybrene (5 $\mathrm{mg} / \mathrm{mL}$ ). When reached $50 \%$ confluence, cells were transfected with recombinant experimental virus or control virus at the optimal MOI (multiplicity of infection) of 50, and cultured at 37 and $5 \% \mathrm{CO}_{2}$ for $4 \mathrm{~h}$. Then supernatant was discarded and serum containing growth medium was added. At 4 days of posttransduction, transduction efficiency was measured by the frequency of green fluorescent protein (GFP)-positive cells. Positive and stable transfectants were selected and expanded for further study. The KiSS1 virus vectorinfected clone, the negative control vectorinfected cells, and MG-63 cells were named as Lv-KiSS1, NC, and CON groups, respectively.

\section{Quantitative real-time PCR}

To quantitatively determine the mRNA expression level of KiSS1 and p38MAPK in the MG-63 cell line, real-time PCR was performed. Total RNA was extracted from each clone using TRIzol according to the manufacturer's protocol. Reverse transcription was carried out using M-MLV and cDNA amplification was per- formed using the SYBR Green Master Mix kit according to the manufacturer's guidelines. The KiSS1 gene was amplified using a specific oligonucleotide primer and the human glyceraldehyde-3-phosphate dehydrogenase (GAPDH) gene was used as an endogenous control. Data were analyzed using the comparative $\mathrm{Ct}$ method $\left(2^{-\Delta \Delta C t}\right)$. Three separate experiments were performed for each clone.

\section{Western blot assay}

MG-63 cells were harvested and extracted using lysis buffer (Tris-HCl, SDS, mercaptoethanol, and glycerol). Cell extracts were boiled for 5 min in loading buffer, and then an equal amount of cell extracts was separated on $15 \%$ SDS-PAGE gels. Separated protein bands were transferred onto polyvinylidene fluoride (PVDF) membranes, which were subsequently blocked in 5\% skim milk powder. Primary antibodies against KiSS1, p38MAPK, and MMP-9 were diluted according to the manufacturer's instructions and incubated overnight at $4{ }^{\circ} \mathrm{C}$. Subsequently, horseradish peroxidase-linked secondary antibodies were added at a dilution of 1:1000 and incubated at room temperature for $2 \mathrm{~h}$. The membranes were washed 3 times with PBS, and the immunoreactive bands were visualized using the ECL Plus Kit according to the manufacturer's instructions. The relative protein levels in different cell lines were normalized to the concentration of GAPDH. Three separate experiments were performed for each clone.

\section{Cell proliferation assay}

Cell proliferation was analyzed using the MTT assay. Briefly, cells infected with KiSS1 virus were incubated in 96-well-plates at a density of $1 \times 10^{5}$ cells per well with DMEM medium supplemented with $10 \%$ FBS. Cells were treated with $20 \mu \mathrm{L}$ of MTT dye at $0,24,48,72,96 \mathrm{~h}$, and subsequently incubated with $150 \mu \mathrm{L}$ of DMSO for $5 \mathrm{~min}$. The color reaction was measured at $570 \mathrm{~nm}$ using an Enzyme Immunoassay Analyzer (Bio-Rad, Hercules, CA). The proliferation activity was calculated for each clone.

\section{Transwell invasion assay}

Transwell filters were coated with Matrigel $(3.9 \mathrm{mg} / \mu \mathrm{L} ; 60-80 \mu \mathrm{L}$ on the upper surface of a polycarbonate membrane (diameter, $6.5 \mathrm{~mm}$; pore size, $8 \mu \mathrm{m})$. After incubating at $37^{\circ} \mathrm{C}$ for $30 \mathrm{~min}$, the Matrigel solidified and served as the extracellular matrix for analysis of tumor cell invasion. Harvested cells $\left(1 \times 10^{5}\right)$ in 100 $\mu \mathrm{L}$ of serum-free DMEM were added into the upper compartment of the chamber. A total of $200 \mathrm{~m} \mu \mathrm{L}$ of conditioned medium derived from NIH3T3 cells was used as a source of chemoattractant, which was placed in the bottom com- 
partment of the chamber. After $24 \mathrm{~h}$ of incubation at $37^{\circ} \mathrm{C}$ with $5 \% \mathrm{CO}_{2}$, the medium was removed from the upper chamber. The noninvaded cells on the upper side of the chamber were scraped off with a cotton swab. Cells that had migrated from the Matrigel into the pores of the inserted filter were fixed with $100 \%$ methanol, stained with hematoxylin, then mounted and dried at $80^{\circ} \mathrm{C}$ for $30 \mathrm{~min}$. The number of cells invading through the Matrigel was counted in 3 randomly selected visual fields from the central and peripheral portion of the filter by using an inverted microscope (200x magnification). Each assay was repeated 3 times.

\section{Statistical analysis}

The SPSS 20.0 software was used for statistical analyses. The Kruskal-Wallis $\mathrm{H}$ test, chisquare test, and one-way analysis of variance (ANOVA) were employed to analyze the expression rate in all groups. The LSD method of multiple comparisons was used when the probability for ANOVA was statistically significant. Significance was defined as $\mathrm{P}<0.05$.

\section{Results}

\section{The expression of KiSS1 in osteo- sarcoma tissues}

The expression of KiSS1 protein was evaluated using IHC staining in OS tissues; as shown in Figure 1, different levels of positive expression of KiSS1 protein were examined in OS tissues. Positive KiSS1 immunostaining was localized in the nucleus and cytoplasm of OS tissue cells. According to the KiSS1 immunoreactive intensity, the positive expression of KiSS1 in OS tissues was significantly decreased compared with that of KiSS1 in ANCT ( $\mathrm{P}=0.023)$ (Table 1).

\section{Association between KiSS1 expres- sion and clinicopathologic charac- teristics}

The association of KiSS1 expression with various clinical and pathologic factors was analyzed. As shown in Table 2, KiSS1 expression was closely correlated with distant metas- tasis of OS $(\mathrm{P}=0.019)$. However, no significant correlation was found between KiSS1 expression and other factors including age, gender of the patients, and histology and Ennecking staging of the tumor ( $\mathrm{P}>0.05$, separately).

\section{The effect of KiSS1 overexpression on the expression of p38MAPK}

After OS MG-63 cells were stably transfected with Lv-KiSS1, the mRNA and protein expression levels of KiSS1 and p38MAPK were detected by real-time PCR (Figure 2 A,B) and Western blot assays (Figure $2 \mathrm{C}, \mathrm{D}$ ). The results showed that the expression of KiSS1 was remarkably increased, while that of p38MAPK was decreased in Lv-KiSS1 group compared to $\mathrm{NC}$ and $\mathrm{CON}$ groups $(\mathrm{P}<0.01$, each).

\section{The effect of KiSS1 overexpression on cell proliferation}

Deregulated cell proliferation is a hallmark of cancer. ${ }^{16}$ To know about the effect of KiSS1 overexpression on tumor growth in OS MG-63 cells, we evaluated the proliferative activities of MG-63 cells by MTT assay. We found that KiSS1 overexpression markedly suppressed the proliferative activities of MG-63 cells in a time-dependent manner compared to $\mathrm{NC}$ and CON groups (Figure 3).

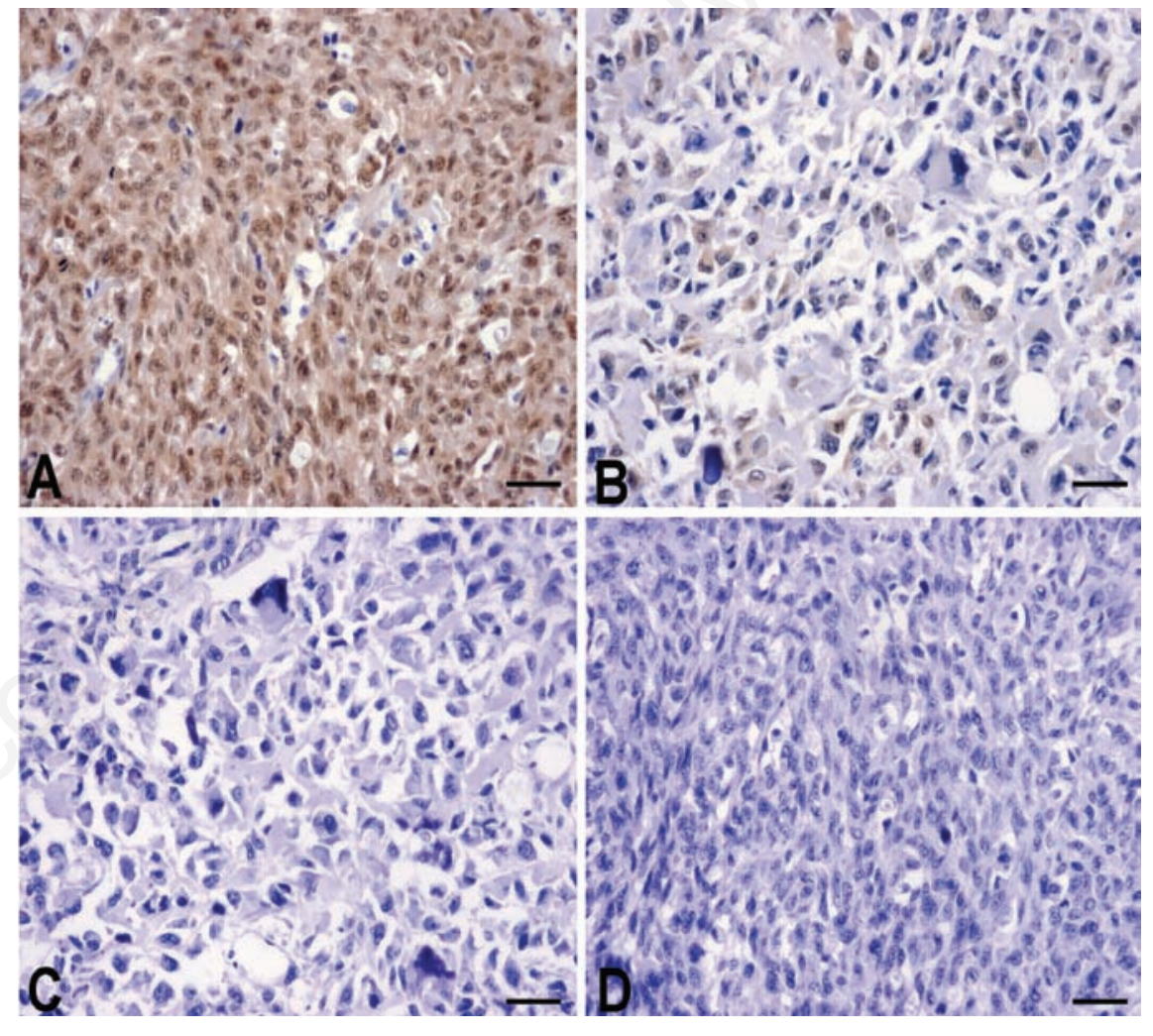

Figure 1. The expression of KiSS1 protein in osteosarcoma tissues (magnification $\times 200$ ) Adjacent non-cancer tissues were immunohistochemically stained with an anti-KiSS1 antibody and classified as positive (A) and negative (C) expression. Osteosarcoma tissues were immunohistochemically stained with an anti-KiSS1 antibody and classified as positive (B) and negative (D) expression. Positive immunostaining of KiSS1 was mainly localized in the nucleus and cytoplasm of tumor and tissue cells. Scale bars: $75 \mathrm{~m}$.

Table 1. The expression of KiSS1 protein in osteosarcoma tissues.

\begin{tabular}{lcccccccccc} 
Target & Sample & & \multicolumn{3}{c}{ Number } & & Total & Positive rate (\%) & $\chi^{2}$ \\
KiSS1 & OS & 23 & 11 & 4 & 2 & 40 & 42.5 & P \\
& ANCT & 12 & 18 & 7 & 3 & 40 & 70.0 & 5.175 & 0.023 \\
\hline
\end{tabular}

0, negative, +, score 1-3; ++, score 4-6; +++, score 7-9; ++++, score 10-12; OS, osteosarcoma; ANCT, adjacent non-cancer tissue. 


\section{The effect of KiSS1 overexpression on cell invasion}

To determine the effect of KiSS1 overexpression on the invasive potential of MG-63 cells, a Transwell assay was performed. The invasive potential of tumor cells in Transwell assay was determined by the ability of cells to invade a matrix barrier containing laminin and type IV collagen, the major components of the basement membrane. Representative micrographs of Transwell filters can be seen in Figure 4A. We found that the invasive potential of OS cells was apparently decreased in LvKiSS1 group compared to NC and CON groups $(\mathrm{P}<0.01)$ (Figure 4B). To understand the molecular mechanisms of KiSS1 on cell invasion, we examined the expression of MMP-9 in Lv-KiSS1-transfected OS cells by Western blot assay (Figure $4 \mathrm{C}, \mathrm{D}$ ), and found that the expression level of MMP-9 was significantly reduced in Lv-KiSS1 group compared to $\mathrm{NC}$ and CON groups $(\mathrm{P}<0.01)$.

\section{Discussion}

KiSS1 has been originally identified as a metastasis-suppressor gene able to inhibit tumor progression. The expression of KiSS1 is found be decreased in many tumors, ${ }^{17-19}$ and the loss of KiSS1 expression correlates with the progression of lymph node metastasis in human colorectal cancer, ${ }^{18}$ indicating the unfavorable prognosis for disease outcome. ${ }^{19}$ Some studies reveal that KiSS1 mRNA expression is also markedly reduced in tissues of breast cancer, ${ }^{20}$ while other ones show that KiSS1 is highly expressed in estrogen receptor (ER)positive breast tumors compared to the ERnegative tumors. ${ }^{21} \mathrm{KiSS} 1$ expression levels are found to be decreased in OS cell lines with increasing aggressiveness, while increases in human OS tissues and correlates with the metastasis of $0 .^{22}$ Differently from the study of Wang et al., ${ }^{22}$ we found in the present study that KiSS1 was proved to be decreased in the nucleus and cytoplasm of human OS tissues compared to the ANCT, suggesting that loss of KiSS1 expression might be involved in the development of OS.

Many studies have demonstrated that KiSS1, a key regulator of puberty, is discovered as a tumor metastasis suppressor. In addition to the reduced or lost expression of KiSS1 in different metastatic tumors, overexpression of KiSS1 inhibits growth and invasion of tumor cells through inhibition of RhoA-mediated NF$\mathrm{kB}$ activation. ${ }^{23,24}$ However, individual study has indicated that new clones expressing KiSS1 show no decrease in metastatic growth, and metastasis suppressor KiSS1 lacks anti-
Table 2. Association of HMGB1 expression with clinicopathological factors of osteosarcoma patients.

\begin{tabular}{|c|c|c|c|c|}
\hline Variables & Cases & & & $\mathbf{P}$ \\
\hline & (n) & - & + & \\
\hline Total & 40 & 23 & 17 & \\
\hline $\begin{array}{c}\text { Age (years) } \\
\quad<20 \\
\geq 20\end{array}$ & $\begin{array}{l}26 \\
14\end{array}$ & $\begin{array}{c}15 \\
8\end{array}$ & $\begin{array}{c}11 \\
6\end{array}$ & 0.974 \\
\hline $\begin{array}{l}\text { Gender } \\
\text { Male } \\
\text { Female }\end{array}$ & $\begin{array}{l}24 \\
16\end{array}$ & $\begin{array}{c}15 \\
8\end{array}$ & $\begin{array}{l}9 \\
8\end{array}$ & 0.439 \\
\hline $\begin{array}{l}\text { Histology } \\
\text { Osteoblastic } \\
\text { Chondroblastic } \\
\text { Fibroblastic } \\
\text { Others }\end{array}$ & $\begin{array}{l}15 \\
13 \\
8 \\
4\end{array}$ & $\begin{array}{l}8 \\
8 \\
5 \\
2\end{array}$ & $\begin{array}{l}7 \\
5 \\
3 \\
2\end{array}$ & 0.949 \\
\hline $\begin{array}{l}\text { Ennecking staging } \\
\text { I } \\
\text { I } \\
\text { III }\end{array}$ & $\begin{array}{c}9 \\
27 \\
4\end{array}$ & $\begin{array}{c}6 \\
14 \\
3\end{array}$ & $\begin{array}{c}3 \\
13 \\
1\end{array}$ & 0.567 \\
\hline $\begin{array}{l}\text { Distant metastases } \\
\text { No } \\
\text { Yes }\end{array}$ & $\begin{array}{l}13 \\
27\end{array}$ & $\begin{array}{c}4 \\
19\end{array}$ & $\begin{array}{l}9 \\
8\end{array}$ & 0.019 \\
\hline
\end{tabular}
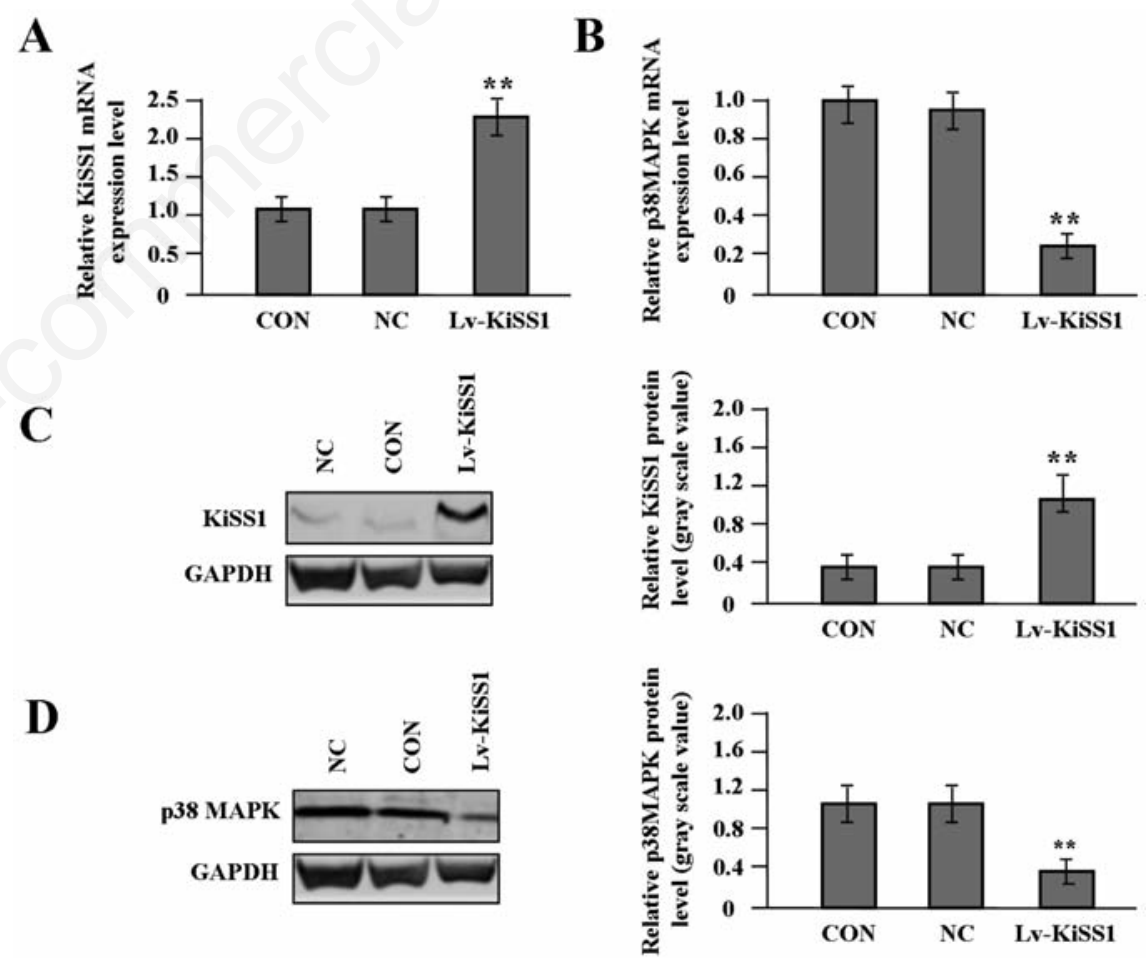

Figure 2. The effect of KiSS1 overexpression on the expression of p38MAPK in OS cells. After OS MG-63 cells were transfected with Lv-KiSS1 for $24 \mathrm{~h}$, the expression levels of KiSS1 and p38MAPK were detected by real-time PCR (A, B) and Western blot assays (C, D). The expression of KiSS1 was significantly increased, but that of p38MAPK was decreased in the KiSS1 virus vector-infected clone (Lv-KiSS1) group compared with the MG-63 cells (CON) and the negative control vector-infected cells (NC) groups (each ** $\mathbf{P}<\mathbf{0 . 0 1 )}$. 
metastatic activity in melanoma. ${ }^{25}$ Nevertheless, our present study showed that overexpression of KiSS1 inhibited growth and invasion of OS cells with decreased expression of p38MAPK, suggesting that KiSS1 might function as a tumor suppressor in OS through regulation of the MAPK signaling.

Evidence indicates that elevated expression of interstitial collagenases including MMP-9 is associated with a poor prognosis in a variety of cancers and serves as a marker of tumor progression. ${ }^{26}$ KiSS1 expression is found lowered in hepatocellular carcinoma (HCC), and has a negative correlation with MMP-9 expression, suggesting a possible mechanism for cell motility and invasion during tumor metastasis. ${ }^{27}$ KiSS1, a metastasis suppressor gene, exerts its influence on invasion phenotype through inhibition of NF- B signaling, which in turn regulates MMP-9 production facilitating invasion. ${ }^{28}$ KiSS1 suppresses MMP-9 expression by activating the p38 MAPK signaling pathway in stomach cancer. ${ }^{29}$ However, our present study indicated that KiSS1 inhibited the expression of p38 MAPK and MMP-9 and tumor growth and invasion in OS cells, while inhibition of p38 MAPK pathway decreases the expression of MMP-9 in OS cells, ${ }^{30}$ suggesting KiSS1 might have anti-tumor effect through inhibition of MAPK-mediated MMP-9 expression in OS cells.

In conclusion, our findings indicate that KiSS1 expression is downregulated in OS tissues, and KiSS1 may function as a tumor sup-

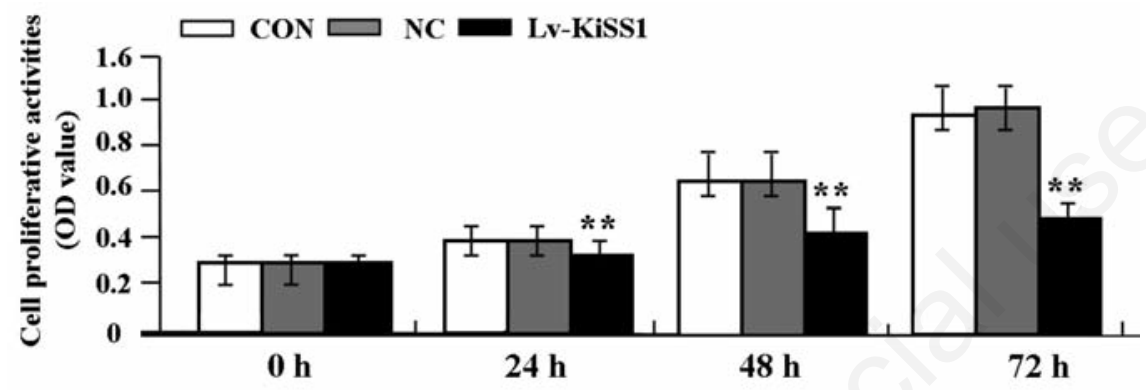

Figure 3. The effect of KiSS1 overexpression on cell proliferation. After OS cells were transfected with Lv-KiSS1, MTT assay was used to evaluate cell proliferative activity for consecutive 3 days. Cell proliferative activity was remarkably inhibited as a time-dependent manner in the KiSS1 virus vector-infected clone (Lv-KiSS1) group compared with the MG-63 cells (CON) and the negative control vector-infected cells (NC) groups (each ** $\mathbf{P}<0.01)$.

A

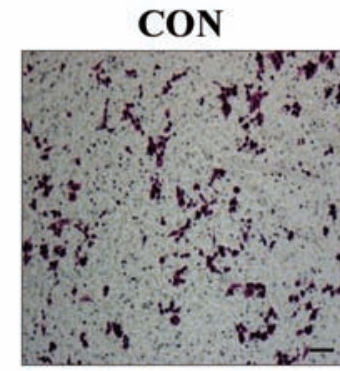

B

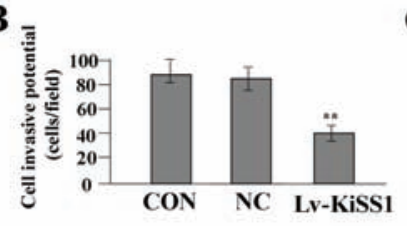

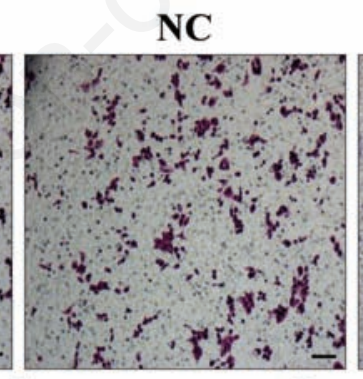

C

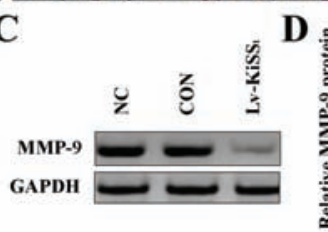

\section{Lv-KiSS1}
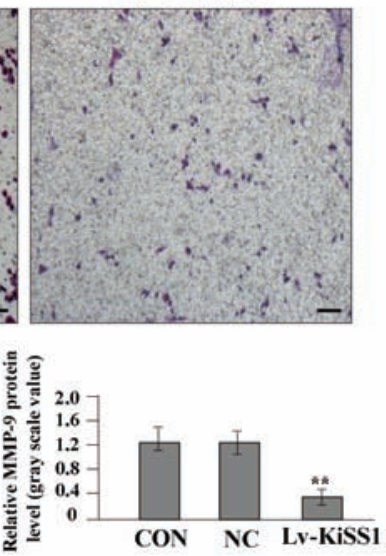

Figure 4. The effect of KiSS1 overexpression on cell invasion. After OS MG-63 cells were transfected with $\mathrm{Lv}$-KiSS1, Transwell assay was performed to determine cell invasive potential. A, B) Cell invasive potential was markedly weakened in Lv-KiSS1 group compared with the CON and NC groups $\left({ }^{* *} \mathrm{P}<0.01\right)$. C, D) The expression level of MMP-9 protein, examined by Western blot assay, was significantly downregulated in the KiSS1 virus vector-infected clone ( $\mathrm{Lv}$-KiSS1) group compared with the MG-63 cells $(\mathrm{CON})$ and the negative control vector-infected cells (NC) groups $(* * P<0.01)$. Scale bars: A, $75 \mathrm{~m}$.

pressor in OS cells through inhibition of MAPK pathway, suggesting that KiSS1 may serve as a potential therapeutic target for the treatment of cancer.

\section{References}

1. Jaffe N. Osteosarcoma: review of the past, impact on the future. The American experience. Cancer Treat Res 2009;152:239-62.

2. Bielack SS, Kempf-Bielack B, Delling G, Exner GU, Flege S, Helmke $\mathrm{K}$, et al. Prognostic factors in high-grade osteosarcoma of the extremities or trunk: an analysis of 1,702 patients treated on neoadjuvant cooperative osteosarcoma study group protocols. J Clin Oncol 2002;20:77690.

3. Kong C, Hansen MF. Biomarkers in osteosarcoma. Expert Opin Med Diagn 2009;3: 13-23.

4. Porzionato A, Fenu G, Rucinski M, Macchi V, Montella A, Malendowicz LK, et al. KISS1 and KISS1R expression in the human and rat carotid body and superior cervical ganglion. Eur J Histochem 2011;55:e14.

5. Stiles JM, Rowntree RK, Amaya C, Diaz D, Kokta V, Mitchell DC, et al. Gene expression analysis reveals marked differences in the transcriptome of infantile hemangioma endothelial cells compared to normal dermal microvascular endothelial cells. Vasc Cell 2013;5:6.

6. Beck BH, Welch DR. The KISS1 metastasis suppressor: a good night kiss for disseminated cancer cells. Eur J Cancer 2010;46: 1283-9.

7. Sanchez-Carbayo M, Capodieci P, CordonCardo C. Tumor suppressor role of KiSS-1 in bladder cancer: loss of KiSS-1 expression is associated with bladder cancer progression and clinical outcome. Am J Pathol 2003;162:609-17.

8. Dhar DK, Naora H, Kubota H, Maruyama $\mathrm{R}$, Yoshimura $\mathrm{H}$, Tonomoto $\mathrm{Y}$, et al. Downregulation of KiSS-1 expression is responsible for tumor invasion and worse prognosis in gastric carcinoma. Int $\mathbf{J}$ Cancer 2004;111:868-72.

9. Cebrian V, Fierro M, Orenes-Piñero E, Grau L, Moya P, Ecke T, et al. KISS1 methylation and expression as tumor stratification biomarkers and clinical outcome prognosticators for bladder cancer patients. Am J Pathol 2011;179:540-6.

10. Moya P, Esteban S, Fernandez-Suarez A, Maestro M, Morente M, Sánchez-Carbayo M. KiSS-1 methylation and protein expression patterns contribute to diagnostic and prognostic assessments in tissue specimens for colorectal cancer. Tumour Biol 
2013;34:471-9.

11. Jiffar T, Yilmaz T, Lee J, Hanna E, ElNaggar A, Yu D, et al. KiSS1 mediates platinum sensitivity and metastasis suppression in head and neck squamous cell carcinoma. Oncogene 2011;30:3163-73.

12. McNally LR, Welch DR, Beck BH, Stafford LJ, Long JW, Sellers JC, et al. KISS1 overexpression suppresses metastasis of pancreatic adenocarcinoma in a xenograft mouse model. Clin Exp Metastasis 2010; 27:591-600.

13. Schmid K, Wang X, Haitel A, Sieghart W, Peck-Radosavljevic M, Bodingbauer M, et al. KiSS-1 overexpression as an independent prognostic marker in hepatocellular carcinoma: an immunohistochemical study. Virchows Arch 2007;450:143-9.

14. Marot D, Bieche I, Aumas C, Esselin S, Bouquet C, Vacher S, et al. High tumoral levels of KiSS1 and G-protein-coupled receptor 54 expression are correlated with poor prognosis of estrogen receptor-positive breast tumors. Endocr Relat Cancer 2007;14:691-702.

15. Martin TA, Watkins G, Jiang WG. KiSS-1 expression in human breast cancer. Clin Exp Metastasis 2005;22:503-11.

16. Hanahan D, Weinberg RA. The hallmarks of cancer: the next generation. Cell 2011; 144:646-74.

17. Martínez-Fuentes AJ, Molina M, VázquezMartínez R, Gahete MD, Jiménez-Reina L, Moreno-Fernández J, et al. Expression of functional KISS1 and KISS1R system is altered in human pituitary adenomas: evidence for apoptotic action of kisspeptin10. Eur J Endocrinol 2011;164:355-62.

18. Okugawa Y, Inoue Y, Tanaka K, Toiyama Y, Shimura T, Okigami M, et al. Loss of the metastasis suppressor gene KiSS1 is associated with lymph node metastasis and poor prognosis in human colorectal cancer. Oncol Rep 2013 [Epub ahead of print].

19. Sun YB, Xu S. Expression of KISS1 and KISS1R (GPR54) may be used as favorable prognostic markers for patients with nonsmall cell lung cancer. Int J Oncol 2013;43: $521-30$.

20. Mooez S, Malik FA, Kayani MA, Rashid R, Zahid A, Khan A. Expressional alterations and transcript isoforms of metastasis suppressor genes (KAIl and KiSS1) in breast cancer patients. Asian Pac J Cancer Prev 2011;12:2785-91.

21. Jarząbek K, Kozłowski L, Milewski R, Wołczyński S. KiSS1/GPR54 and estrogenrelated gene expression profiles in primary breast cancer. Oncol Lett 2012;3:930934.

22. Wang FS, Chen H, Wu ZY, Lin JH. KISS1 expression in osteosarcoma: high in chinese clinical cases, but lower in cell lines. Asian Pac J Cancer Prev 2011;12:3229-34.

23. Cho SG, Li D, Stafford LJ, Luo J, Rodriguez-Villanueva M, Wang Y, et al. KiSS1 suppresses TNFalpha-induced breast cancer cell invasion via an inhibi- tion of RhoA-mediated NF-kappaB activation. J Cell Biochem 2009;107:1139-49.

24. Li N, Wang HX, Zhang J, Ye YP, He GY. KISS-1 inhibits the proliferation and invasion of gastric carcinoma cells. World J Gastroenterol 2012;18:1827-33.

25. Navenot JM, Evans B, Oishi S, Setsuda S, Fujii N, Peiper SC. The metastasis suppressor KISS1 lacks antimetastatic activity in the C8161.9 xenograft model of melanoma. Melanoma Res 2012;22:140-50.

26. Brinckerhoff CE, Rutter JL, Benbow U. Interstitial collagenases as markers of tumor progression. Clin Cancer Res 2000; 6:4823-30.

27. Shengbing Z, Feng LJ, Bin W, Lingyun G, Aimin H. Expression of KiSS-1 gene and its role in invasion and metastasis of human hepatocellular carcinoma. Anat Rec (Hoboken) 2009;292:1128-34.

28. Teng Y, Liu M, Cowell JK. Functional interrelationship between the WASF3 and KISS1 metastasis-associated genes in breast cancer cells. Int J Cancer 2011;129: 2825-35.

29. Lee KH, Kim JR. Kiss-1 suppresses MMP-9 expression by activating p38 MAP kinase in human stomach cancer. Oncol Res 2009;18:107-16.

30. Tingting R, Wei G, Changliang P, Xinchang L, Yi Y. Arsenic trioxide inhibits osteosarcoma cell invasiveness via MAPK signaling pathway. Cancer Biol Ther 2010;10:251-7. 